\title{
Effect of Zinc and Selenium Fortification of Diet on Hematological and Biochemical Parameters of Fasciola Infected Ewes
}

\author{
Samak, M.A. ${ }^{*}$, I.A. El-Sayed ${ }^{* *}$, A. Hassan ${ }^{*}$ and A.A. \\ El-Mgdoub*. \\ * Department of Animal Production, Faculty of \\ Agriculture, University of Alexandria, Egypt. \\ ** Animal Production Res. Inst., Dokki, Giza, Egypt.
}

AN experiment was designed to investigate the effect of fortify. ing rations with Zinc and/or Selonium on physiologica! performance of fasciola infected ewes. Biweekly blood samples, for 8 weeks perioci, from thirty naturally fasciola infected Barki ewes were taken and analysed for packed cell volume (PCV), haemoglolbin concentration (Hb), erythrocyte and total leucocyte and it's differential counts. Three Wintrobe indexes (MCV, MCH and MCHC) were also calculated. Blood plasma Zinc and Selenium were determined. Feacal parasite egg was also counted. Results indicated that adding Selenium alone or in combination with Zinc to the ration significantly increased erythrocyte counts but decreased leucocyte counts as compared to adding Zinc alone. The decrease in total leucocytes by adding Selenium or Selenium with Zinc was reflected in a significantly decrease in lymphocytes, neutrophils, eosinophils and basophilic cells. Monocytes was signiricantly decreased by Zine fortification as compared to other treatments PCV as well as $\mathrm{Hb}$ were significantly increased by Selenium and Zinc/Selenium fortification. Results also showed that MCV and MCH decreased but MCHC increased significantly by treatments not Zine fortification alone. Fwes body weight and plasma Zinc were not significantly different as a result of different treatments. Blood plasma Solenium was increased after Selenium fortification. Throughout the \& weeks of the exporimental period, erythrocytes, PCV, Mb, MCHC, plasma Zine, Selenium and body weight had steadily increased. Total and differential ieucocytic counts except that of the basophils as well as MCH and MCV were 1ecreased. 
Fascioliasis is a wicspited disease of cattie and sheep (Daws, 1963 and Soulsby, 1973). The prevalence of infection with Fasciola sp. among cattie
had also been reporied by many researchers (Combanas, kass et al., 1968). The infection reduees as decreases body weight gain wiend and meat quatity as well (Pantilouris, 1965; Dueli, 1975 and found to cause decrease in exythrocyte et al, 1977). The parasite was also and inorganic phosphorus (Jennings counts, naemggiobin level, aibumin Holms, 1968 and El-Magdoub ciated with eosinophilin asub, 1970). On the other hand lcucocytosis assoby (Balbo et al., 1973 and Issoref as high biood plasma protein were reported ever may counieract the High plane of nutrition, howon high protein rations withage caused by the fiukes. Infected animais fed. cell volume (Dimtroy et al 1978 without trace elements level and packed jective of the present study was to and Oaciy et ah, 1979). Therefore the obwith zine and/or selenium ewes.

$$
\text { Material and Nethods }
$$

Animals, feeding and management

Thirty naturally fasciola infected Barki ewes of the same age and weight were used in the present study. Ewes were left to graze on berseem Tri. and $150 \mathrm{gm}$. of cotton allowance of about $450 \mathrm{gm}$. of straw $1 \%$ ordinary salt and $210 \%$ per day, (Morrison, 1957) in addition to divided randomly into 3 groups carbonate of rations weight. Animals were barnes. Ewes in the first group were each which were kept in separate Zine as zinc oxide. Ewes in the singly drenched daily with $60 \mathrm{ppm}$ ppm seienium as sodium selenite were drenched with both zinc and per ewe while those in the third group levels per ewe.

Data, sampling collection and analysis

Biweekly blood samples, for eight weeks period, were taken from eachs

Egypt. J. Anim. Prod. 26, No. 1. (1980) 
animal by Jagular puncture into heparinized test tubes. Blood sampies were analyzed for packed cell volume (PCV), haemoglobin concentration ( $\mathrm{Hb}$ ) and erythrocyte and total leucocyte counts, within 30 min. of sampling. PCV and $\mathrm{Hb}$ were determined according to the method described by Oser (1965) and erythrocytic and leucocytic counts were conducted on an Ao Bright-line haemocytometer. Differential leucocytes distribution was determined using Leishman's stain blood film.

Three wintrobe indexes

Mean corpuscular volume (MCV), mean corpuscular haemoglobin (MCH) and mean corpuscular haemoglobin concentration (MCHC) were calculated using the formulas proposed by Schalm (1965). Samples were then centrifuged at $886 \mathrm{Xg}$ for $20 \mathrm{~min}$. to obtain plasma samples. Blood trace minerals in plasma samples determined using the methods of Mille et al. (1967) and AOAC procedure (1975). Feacal parasite egg counts were carried out as described by Lapage (1965). Ewes were weighted every two weeks to the nearest $100 \mathrm{gm}$.

Data was analyzed as $3 \times 4$ factorial arrangement of treatment in completely randomized design as described by Snedecor and Cochran (1969). Specific differences between treatments were tested using Duncan's Multiple Range Test.

\section{Results and Discussion}

Results indicated that adding selenium alone or in combination with zinc to the ration significantly $(\mathrm{P}<0.01)$ increased the number of erythrocytes in blood of infected ewes as compared to adding zine alone (Table 1). Roland et al. (1979), Said and Handols (1980) and El-Sayed et al., (Under Publication) found that infection with fascioliasis decreased erythrocyte counts. The last authors working on the same bread of infected ewes, found that $\mathrm{RBC}$ reached a low value compared with all of our values (Table 1). These results might give an indication about the beneficial effects of given trace minerals to infected ewes. It was also found, throughout the present experiment, that as period of treatment progressed their was a significantly $(\mathrm{P}<0.01)$ progressive increase in blood erythrocyte counts. However, the rate of increase differed between treatments which was reflected in a significant $(\mathrm{P}<0.01)$ treatment by period interaction. As it can be seen in Fig. (1), ration supplemented with zinc alone did not improve the number 
M.A. SAMAK et al.

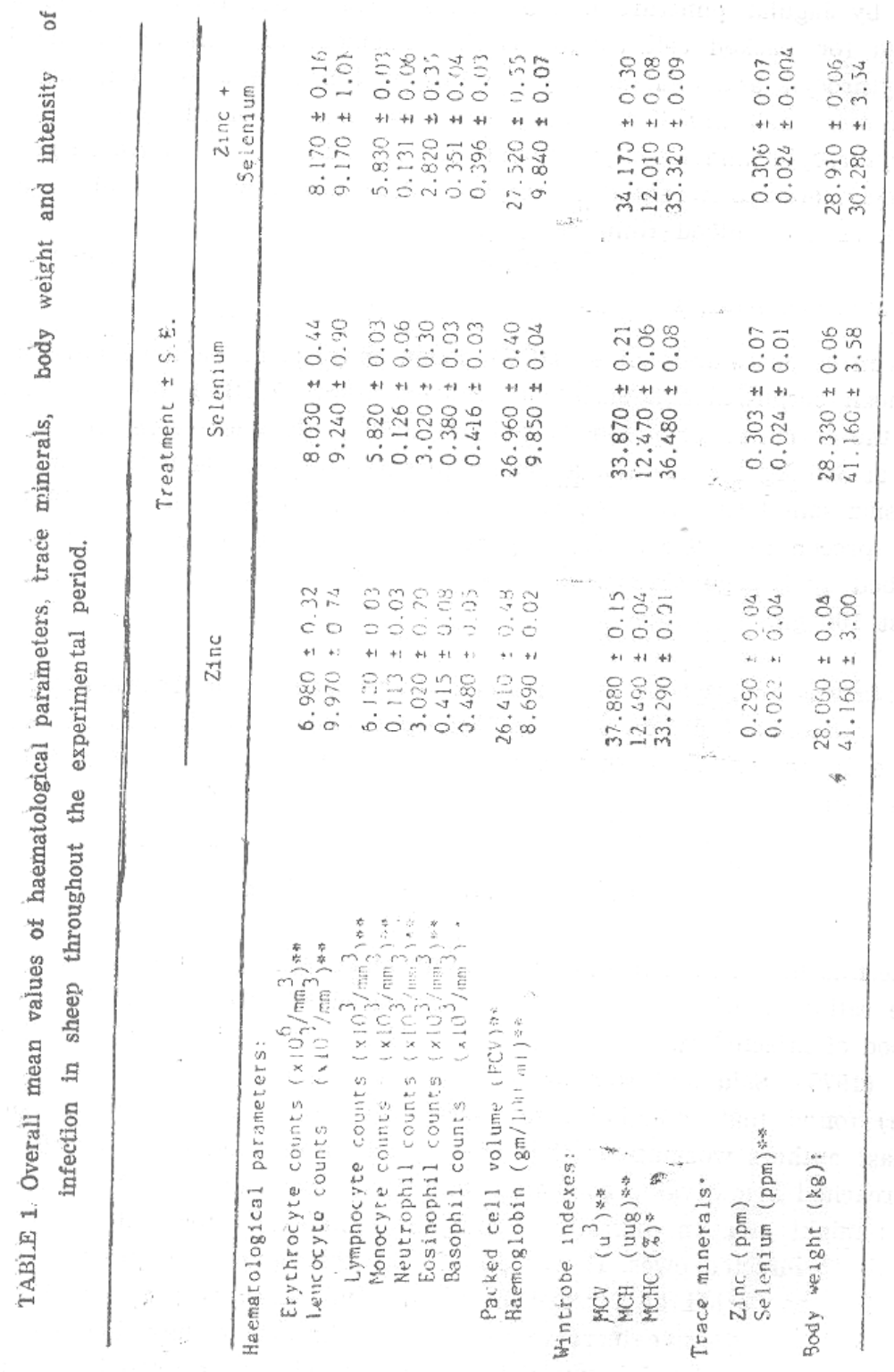

Egypt. J. Anim. Prod. 26, No. 1. (1986) 

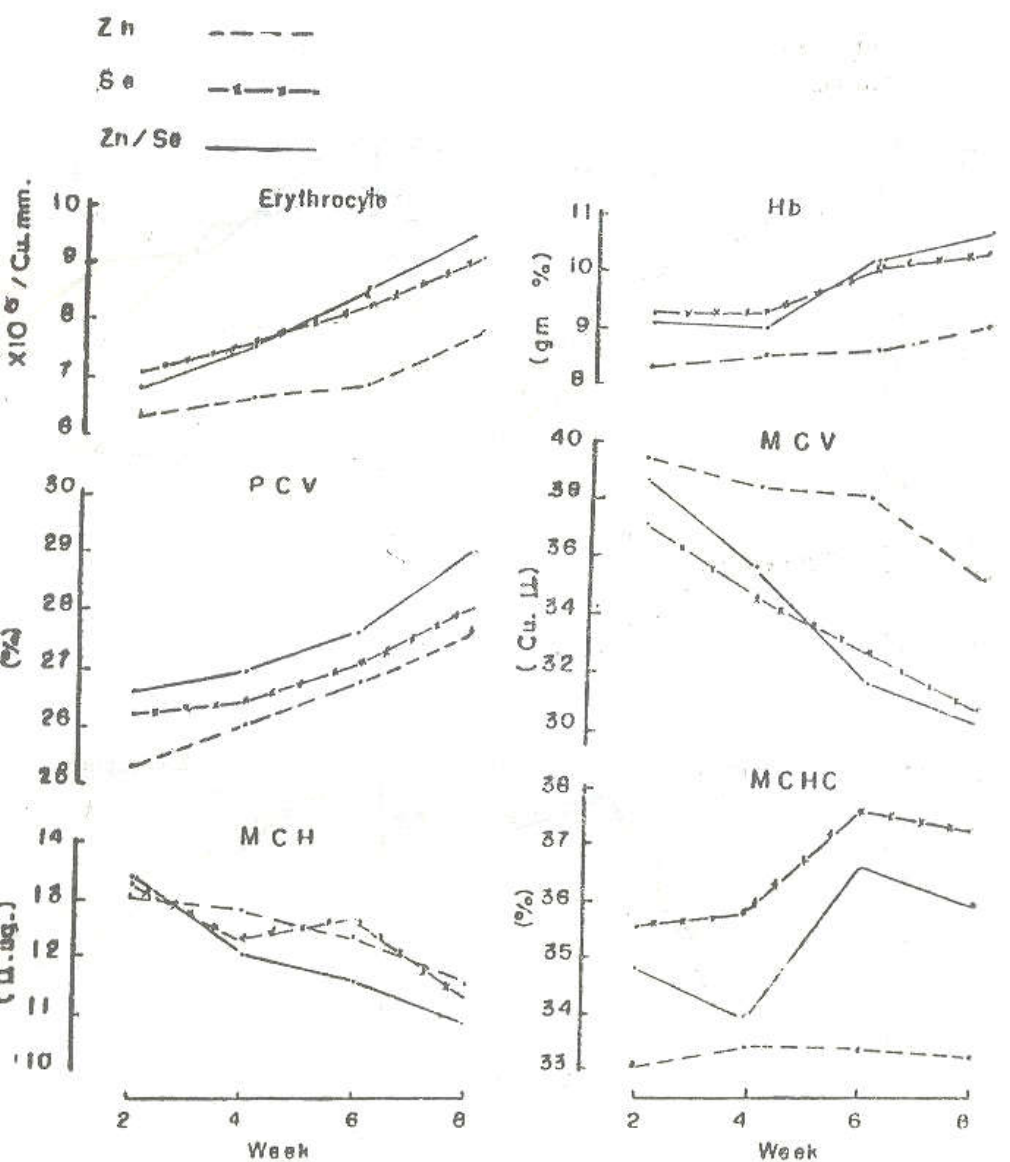

Figure 1. Responses of blood erythrocytes, $\mathrm{Yb}, \mathrm{PCV}$ and wintrob indexes of infected: ewes of ration fortified with Zinc (....), Selenium $(-\mathrm{X}-\mathrm{X}-$ ) and both $(-$ ) throughout eight weeks of experimentation.

of erythrocyte throughout the experiment as much as selenium or zinc with selenium supplementations.

Results also indicated that adding both zinc and selenium to the ration significantly $(\mathrm{P}<0.01)$ decreases the number of leucocytes than did zinc 

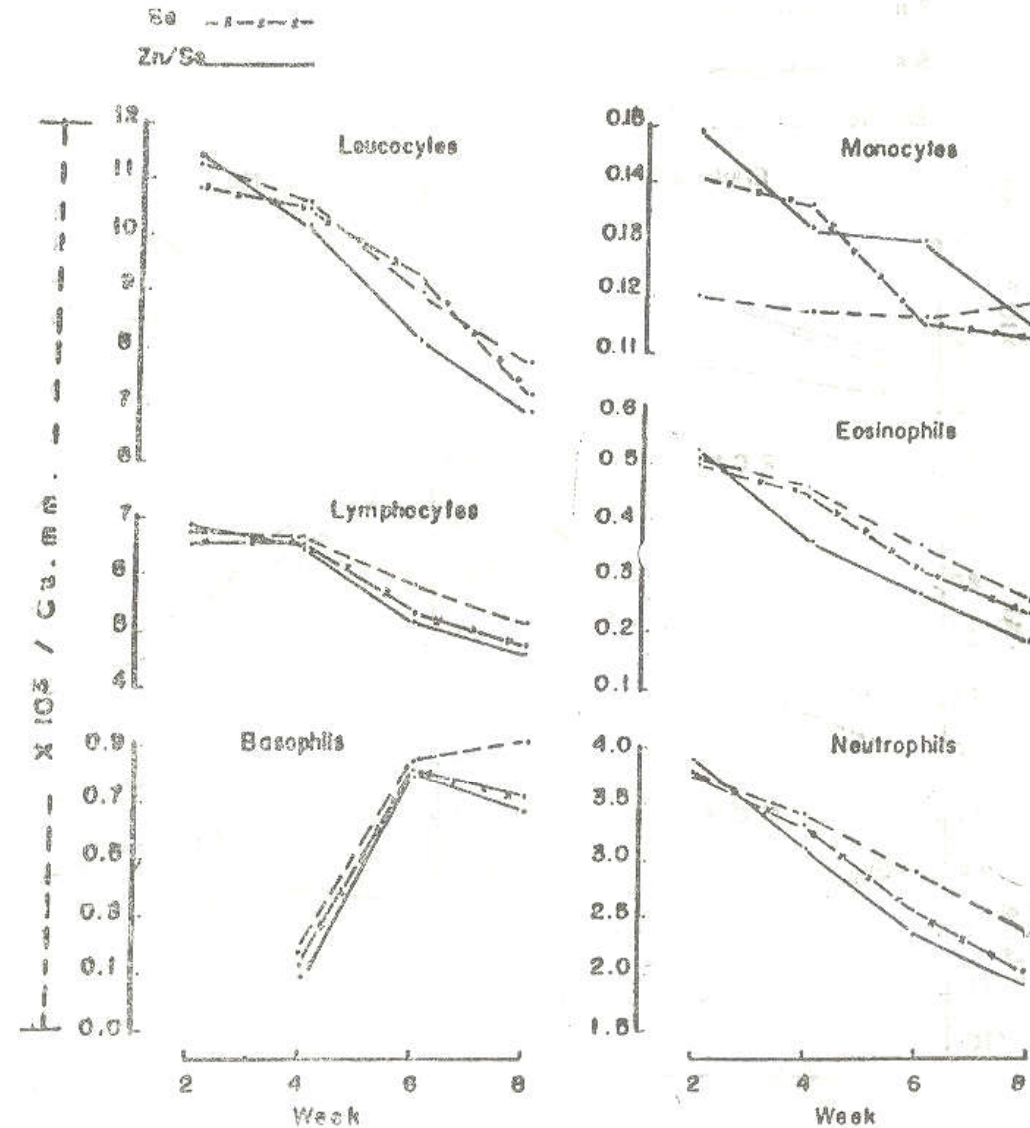

Figure 2, Responses of blood total leucocyte and it's differential counts of infected ewes of ration fortified with Zine $(---)$, Selenium $(-X-X-)$ and both $(-)$ throughout eight weeks of experimentation.

or selenium alone (Table 1). Selenium, however, was more effective than zinc in decreasing the blood leucocyte counts of infected ewes. The number of leucocytes also decreased significantiy as experimental period prosressed in all of the three groups of ewes (Fig. 2). However, the decrease was only drastic after the fourth week of experimentation. It was also found that

Egypt. J. Anim. Prod. 26, No, 1. (1986) 

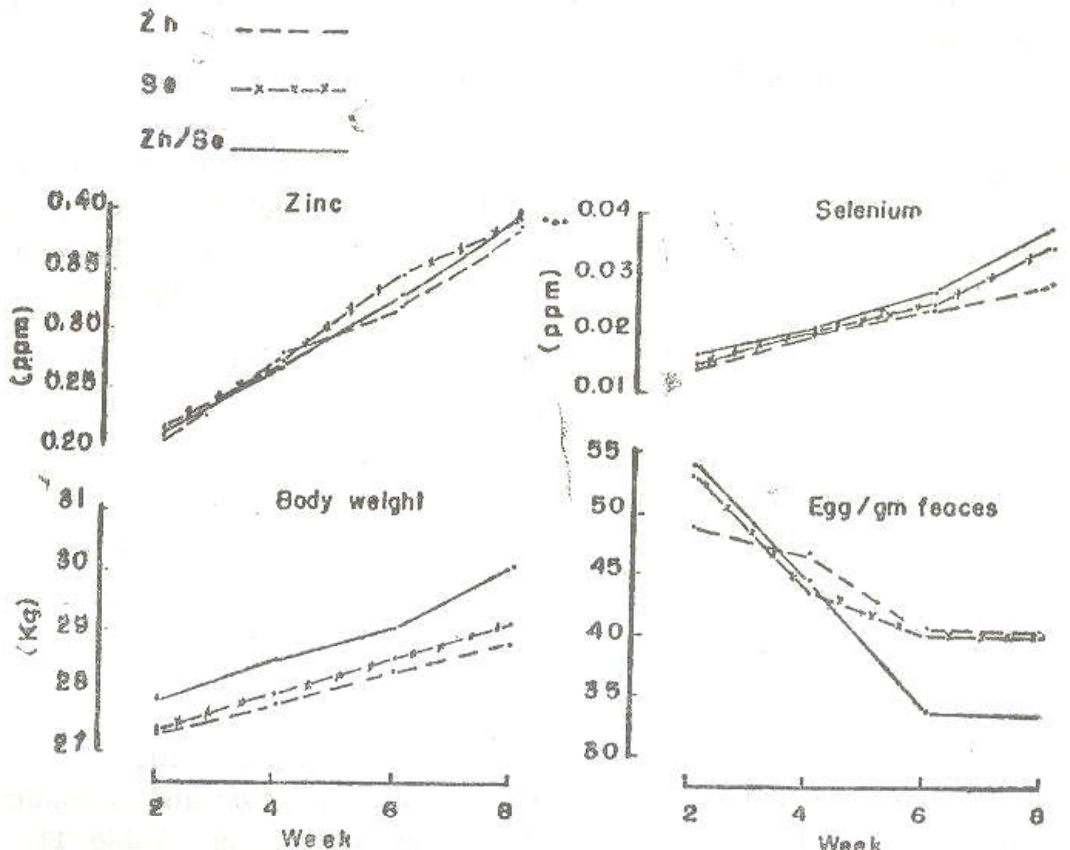

Figure 3. Responses of blood plasma Zinc and Selenium levels, body weight and Egg/gm feaces of infected ewes of ration 'fortified with Zinc (- - $\rightarrow$ ), Selenium $(\mathrm{X}-\mathrm{X}-\mathrm{X}-)$ and both $(\longrightarrow)$ throughout eight weeks of experimentation.

adding both zinc and selenium to the ration was more effective over the duration of the experimentally period than adding any of these trace minerals alone. Lymphocyte counts of infected ewes fed ration fortified with selenium alone or selenium with zine were significantly $(\mathrm{P}<0.01)$ lower than that of the infected ewes fed ration with zine alone (Table 1). It was also found that the number of blood lymphocytes and monocytes of all groups of ewes, fed different ration decreased significantly $(P<0.01)$ and gradually over the successive experimental periods (Fig. 2). The decrease in lymphocyte count was more pronounced when ration fortified with both trace minerals (Fig. 2) reflecting a statistically significant $(\mathrm{P}<0.01)$ interaction between treatments and duration of the experimental period. The present authors found in another study (Under publication) that ewes lymphocytes increased following fasciola infection and explain that by increasing the inflammatory tissue of the ewes. Thus, reduces the lymphocyte numbers by feeding dif- 
ferent trace minerals in the present study might be due to the reduction. in the inflammatory reaction. Results of the present study showed that ration fortified with both minerals zinc and selenium significantly $(P<0.01)$ decreased the number of all of the granulocytic cell counts of the infected ewes (Table 1). differences between values of infected ewes fed ration fortified with zinc or selenium were not significant but they were higher significantly $(\mathrm{P}<0.01)$ than those for ewes fed ration with both minerais. It was found that neutrophilic cell counts and that of eosinophils of ail of the three groups of infected ewes fed on different fortified rations decreased all over the experimental period. However the decrease was more pronounced with those animals fed on ration fortified with both trace minerals (Fig. 2). It was also found that during the first two weeks of the experimental period basophilic cell was not found in the blood of all groups of ewes. However, during the fourth throughout the eighth week of the experimentation basophilic cells started to appear and increased gradually although values decreased little between the sixth throughout the eighth week of experimentation (Fig. 2).

Present results also revealed that PCV increased significantly $(\mathrm{P}<0.01)$ when infected ewes fed on ration fortified with both zinc and selenium as compared to those fed rations with zinc or selenium alone (Table 1). On the other hand, $\mathrm{Hb}$ increased significantiy $(\mathrm{P}<0.01)$ when ewes fed selenium alone or with zinc. Difference between the last two groups was not significant (Table 1 ). Values of $\mathrm{PCV}$ and $\mathrm{Hb}$ were significantiy $(\mathrm{P}<0.01)$ and gradually increased throughout the eighth week of experimentation in all of the three groups of the infected eves, although, it was more pronounced when ewes fed ration with both trace elements (Fig. 1). The increase in $\mathrm{PCV}$ values and $\mathrm{Hb}$ concentrations with erythrocyte counts by adding trace minerals especially zinc and/or selenium suggesied that these minerals might enhance the impaired erythropiotic activity in the infected ewes. Results indicated that feeding both trace minerals decreased significantly $(\mathrm{P}<0.01) \mathrm{MCV}, \mathrm{MCH}$ of infected ewes as compared to other groups. However, feeding ration with selenium alone significantly $(P<0.01)$ decreased $\mathrm{MCH}$ as compared to those fed ration with zinc alone (Table 1).

On the other hand, MCHC was significantly $(\mathrm{P}<0.01)$ higher in the blood of infected ewes fed selenium fortified ration as compared to other treatment groups (Table 1). It was also found that as experimental period progressed up to the eighth week of experimentation there were a signi- 
ficantly $(\mathrm{P}<0.01)$ and gxadually decreased in $\mathrm{MCV}$ and $\mathrm{MCH}$ but increased in MCHC (Fig. 1). Values of MCHC of infected ewes fed ration with zinc were more or less constant at a loC value throughout the duration of the experimental period (Fig. 1). MCHC for the other two groups, however, showed a little decrease at the end of the experimental period (Fig. 1). Differences between blood plasma zinc of infected cwes fed rations fortified with different trace minerals were not statictically significant (Table 1). On the other hand, ewes fed on ration fortified with selenium alone or along with zinc had a significantly $(\mathrm{P}<0.01$ ) higher plasma selenium as compared to ewes fed only zinc (Table 1). The levels of both of those minerals in the infected ewes were low during the first two weeks and then increased gradually by feeding the different trace minerals. Symons et al, (1984) suggested that the deleterious effects of fasciola infections may be due to the impairement of protein metabolism within the animal body which leads to zinc difficiency based on reduced plasma zinc level.

Body weight differences between the three groups of ewes due to feeding zinc and/or selenium in rations were not statistically significant (Table 1). However, body weight of all groups were increased progressively $(\mathrm{P}<0.01)$ as experimental period progressed but the substantial increase was observed with those offered both trace minerals (Fig. 3). Present results, however agreed with those of Horton (1977) and Symons (1984). Results also indicated that infected ewes fed ration with both selenium and zinc had significantly $(\mathrm{P}<0.01)$ low eggs/gm feaces than did those had only zinc or selenium in their ration (Table 1). Differences between the later two groups was not significant. The intensity of the infection in the three experimental groups of infected ewes decreased progressively (Fig. 3). The decrease of the intensity of the infection was more pronounced when fed ration with both trace minerals.

References

Association of Official Analytical Chemists (AOAC). (1975). "Official Method of Analysis», 12th Ed., Washington, D.C.

Babenkas, M.J. Pagirys and V. Alisaukaite (1968), Diagnosis of fascioliasis in farm animals and method of its control in Lithuanian. Acte Parasite, Lithuanica, 7. 121.

Egypt. J. Anim. Prod. 26, No 1. (1986) 
Balbo, T.; Dotta, U.; Abate, O; Guglielmino, R. and Oirardi, C. (1973). Clinical obser. vation on cattle experimentally infected by Fasciola gigantica. Annali della Facolta di medicina verterinaria di Torino, 20 Supplement. 33, 71.

Combanas, A. (1966). Infection with liver flukes in Algeria. Trop. Dis, Bull. 63, 1218

Daws, B. (1963). The migration of juvenile worms of Fasciola hepatica through the wall of the intestines in the mouse with some observations on food and feeding. Parasite. 53, 109

Dimitrov, C; K'necheva, K; and Georgieve, B (1978). Effect of content of protein in the diet for sheep on the development and pathogenic action of $F$. hepatica. Veterinanomeditsinki Nauki. 15, 92.

Duewel, F. and Bossaller, W. (1975). Effects of a single or repeated experimental in. fection with Fasciola hepatica in lambs, particularly with regard to weight and the quality of meat. Proceeding of the 20th World Veterinary Congress, 6-12 July, Saloniki, Greece,

El-Magdoub, I.A. (1970). The effect of nutrition on the resistance of sheep to $F$. gigantica infection. Ph.D. Thesis, Alex. Univ.

El-Sayed, I.A, Samak, M.A., Hassan, A. and El-Magdoub, A.A. (1970). Effect of infection with Fasciola $s p$. on some of ewes blood haematological and biochemical parameters (Under Publication).

Holmes, P.H. and Dargei, J.D. (1968). Albumin and glolbulin turnover in choronic ovin fascioliasis. The Vet. Bult, 39, 199.

Hopes, Cawdery, N.J., K.L Strickland, A. Conway and P.J. Crowe. (1977). Production effects of liver fluke in cattle, the effects of infection on live weight gain, feed intake and food conversion efficiency in beef cattle. British Vet, J. 33, 145.

Horton, G.M. (1977). Selenium and Vitamin E. for lambs with trichostrongylosis. J. Anim Sci. 46,891

Isseroff, H., Joseph, T. Sawma and David Reino. (1977). Fascioliasis. Role of proline in Bile duct hyperplasia. Sci. 198, 4322 .

Jenniges, F.W. and Urhart, G.M. (1965). Radio isotopes studies on the anaemia produced by infection with $F$. hepatica. Exp. Parasite. 5, 458.

Egypt. J. Aním. Prod. 26, No. 1 (1986) 
Lapage, G. (1965). "Monnig's Veterjnary Helminthology and Entomologiy. 5th Bailliere, Tindall and Cox, London.

Mills ,C.F., Dalgrano, A.C., 'Williams, R.B. and Quarterman, J. (1967). Zinc defficiency and the zinc requirements of calves and lambs. Br. J. Nutr, 21, 751.

Morrison, FB. (1957). (Feed and Feeding». The Morrison Publishing Company, Washington.

Morosshkin, B.F., Koctina, A.A., Tvanskii, E.F. and Sutyagen, V.S. (1965). Blood formafion in calves experimentally infected with fasciola. The Vet, Bull. 35, 222.

Oacley, GA., Owen, B. and Knapp, N.H. (1977). Production effects of sub-clinical liver fluke infection in growing dairy heifers. Vet. Record, 104, 503.

Oser, B.L. (1965). "Howk's Physiotogical Chemistry» 14th Ed, TATA McGraw Hill Publishing Co LTD. Bombay, New Delhi.

Panteiouris, E.M. (1965). «The Common Liver Fluke F. hepatica. Pergamon Press 1st Ed. London.

Rowlalnds, D. apt. and Clampitt, RB. (1979). Plasma enzyme levels in ruminants infected with Fasciola hepatica. Vet. Parasit. 5, 155.

Said, S.B. and Handlas, M. (1980). Some blood values of sheep naturally infected with Fasciola hepatica. Prakische Tierazt, 61, 489.

Schalm, O.W. (1965). «Veterinary Haematologu» 2nd Lea and Febiger, Philadelphia

Snedecor, G. and Cochran, W. (1969). In : «Statistical Analysis». lowa State University Press, Ames, Iowa.

Soulsby, EJ.L. (1973). «Textbook of Helminths, Orthopods and Protozoa of Domesticated Animals». 6th ed. Baillre, Tindall and Cassell Ltd. London.

Symons, L.E.A. (1984). Plasma zinc and inapetence in sheep infected with Trichostrongylus colubriformis, J. Comp. Pathol. 93, 547. 


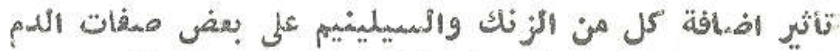

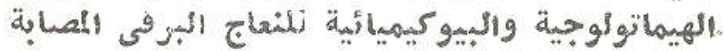

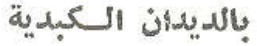

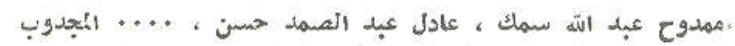

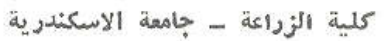

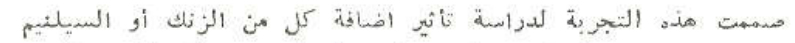

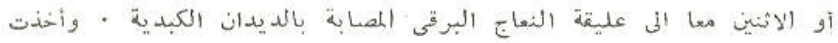

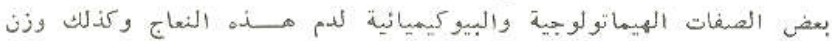

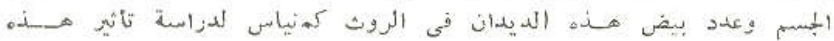

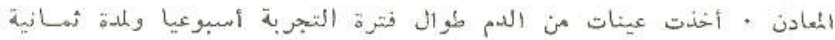

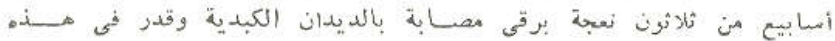

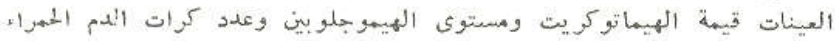

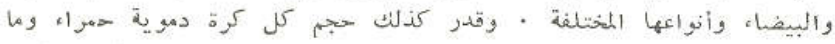

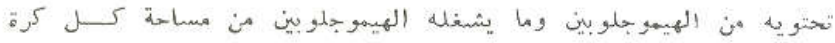

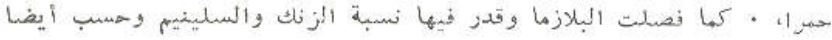

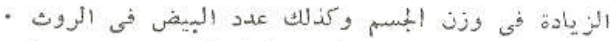

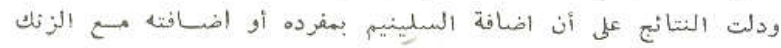

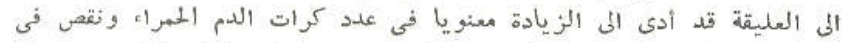

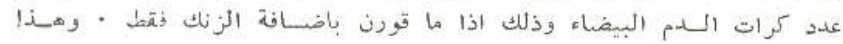

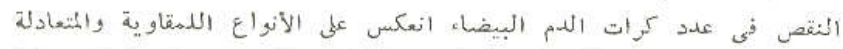

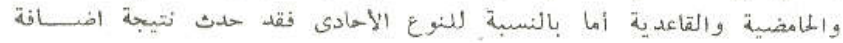

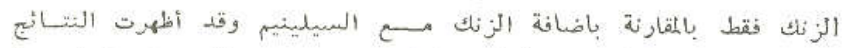

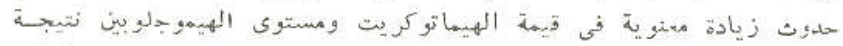

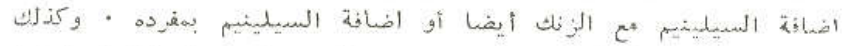

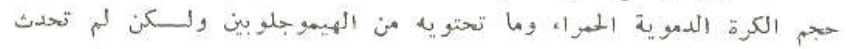

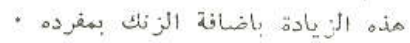

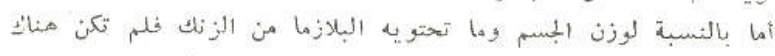

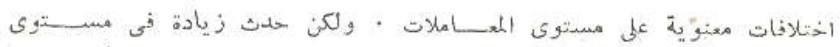

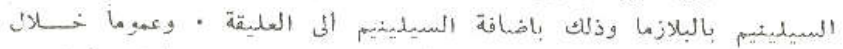

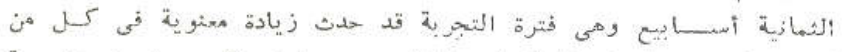

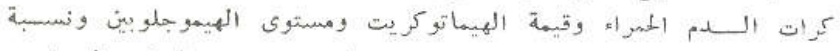

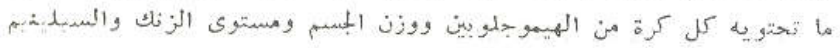

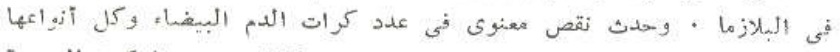

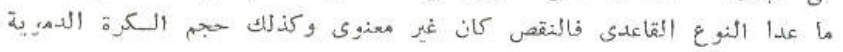

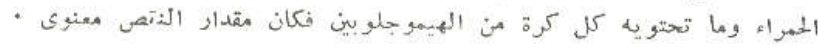

Egypt. J. Anim. Prod. 26, No. 1. (1986) 